\title{
Gallic Acid may have the Potential to Preventing the Development of Preneoplastic Lesions in Liver
}

\section{Rebeca Escutia-Gutierrez and Lourdes Rodríguez-Fragoso*}

Universidad Autónoma del Estado de Morelos, Cuernavaca, Mexico

*Corresponding author: Rodríguez-Fragoso R, Faculty of Pharmacy, Universidad Autónoma del Estado de Morelos, Cuernavaca, Mexico, Tel: 00527773207000 ; Email: mrodriguezf@uaem.mx

Rec date: June 27, 2016; Acc date: June 29, 2016; Pub date: July 07, 2016

Copyright: (c) 2016 Escutia-Gutierrez R et al. This is an open-access article distributed under the terms of the Creative Commons Attribution License, which permits unrestricted use, distribution, and reproduction in any medium, provided the original author and source are credited.

Citation: Escutia-Gutierrez R, Rodríguez-Fragoso L (2016) Gallic Acid may have the Potential to Preventing the Development of Preneoplastic Lesions in Liver. J Liver 5: i102. doi:10.4172/2167-0889.1000i102

\section{Introduction}

It is well known that human chronic liver diseases are characterized by the emergence of preneoplastic lesions of which eventually develop into hepatocellular carcinoma. The dysplastic focus is the characteristic recognizable precursor lesion of HCC.

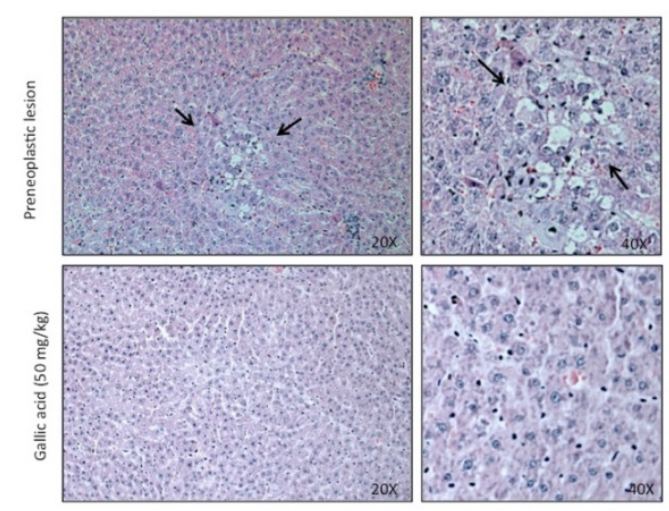

Figure 1: Microscopic images show the potential chemopreventive effect of gallic acid. Preneoplastic lesions were developed in rats by administration of a single dose of DEN (200 mg/Kg i.p) and CCl 4 ( $2 \mathrm{~mL} / \mathrm{kg}$ i.p.) during two weeks. Preneoplastic lesions showed the presence of microscopical small-cell dysplastic focus characterized by loss of liver tissue architecture, changes in nuclear morphology, cellular pleomorphism and cell mitosis (arrows). The gallic acid (50 $\mathrm{mg} / \mathrm{kg}$ p.o.) was given during five weeks previous to the induction of preneoplastic lesions. Animals pretreated with gallic acid maintained the morphological architecture of liver and no cells in mitosis were observed.
In the last decades, several studies have shown the chemopreventive potential of different polyphenols in cancer [1]. Particularly, the gallic acid have shown possess several protective properties anti-cancer as anti-proliferative, pro-apoptotic and anti-tumorigenic effects in vitro and in vivo models [2]. Gallic acid has shown to have a significant chemopreventive effect on development of hepatic preneoplastic lesions in rats. Gallic acid maintains the organization of liver tissue and avoids the development of changes in nuclear morphology, reduces the cellular pleomorphism and the number of cells in mitosis (Figure 1).

\section{References}

1. Lewandowska H, Kalinowska M, Lewandowski W, Stępkowski TM, Brzoska $\mathrm{K}$ (2016) The role of natural polyphenols in cell signaling and cytoprotection against cancer development. J Nutr Biochem 32: 1-19.

2. Verma S, Singh A, Mishra A (2013) Gallic acid: molecular rival of cancer. Environ Toxicol Pharmacol 35: 473-85. 